\title{
THEORISING THE FALL[S] OF COMMUNISM
}

\author{
PRZEMYS $Ł A W$ SADURA, UPADEK KOMUNIZMU \\ W EUROPIE ŚRODKOWO-WSCHODNIEJ \\ W PERSPEKTYWIE WSPÓŁCZESNYCH TEORII REWOLUCJI
}

Krzysztof Świrek

University of Warsaw

It is a commonplace to perceive revolutions as a form of theatre, with an assortment of roles and historical costumes to provide a frame for the actors' actions. Equally important is the way past revolutions are used in the day-to-day theatre of politics, especially in democratic states. The heritage of every revolution is controversial and is used in forming the symbolic background for current political actions. This holds true for the most important revolutionary events in history - the French and October revolutions to name the most obvious cases - but also for events that have a local character. Some revolutions, though, are even more problematic: the dilemma begins not with the evaluation of their outcomes and possible future symbolic uses but when we want to answer the question of whether they were revolutions at all.

The processes that dismantled authoritarian regimes in East-Central Europe around the end of the 1980s and beginning of 1990s are examples of this situation. Should we treat the fall of "real socialism" as a revolutionary break or only as a transfer of power with system-changing consequences? Did that fall more resemble a mass political upheaval of the nineteenth-century sort or just a change of regime - a major change, but negotiated and controlled? Lastly, even when we state that those events bear no resemblance to historical stereotypes of revolution (there was no 
Bastille to seize, nor shot from the Aurora to mark its beginnings) does it mean that we should abandon attempts to discern revolutionary potential in those events?

These questions are addressed by Przemysław Sadura in his book Upadek komunizmu w Europie Środkowo-Wschodniej w perspektywie wspótczesnych teorii rewolucji [The Fall of Communism in East-Central Europe from the Viewpoint of Contemporary Theories of Revolution]. Sadura analyses six countries in the region - Poland, Hungary, Czechoslovakia, the German Democratic Republic, Bulgaria, and Romania - to show that the fall of communism was indeed revolutionary in character. Yet those revolutions did not follow the same pattern: each one differs; each one should be treated as an assemblage of specific circumstances that had a major influence on the nature of the process. At the same time, thanks to a comparative perspective, it is possible to build a model that explains the specific, differing patterns of the revolutionary events occurring in each country that underwent a major change of power around the year 1989. Sadura proposes such a model, but before describing it I would like to address the timeliness of his book.

The book came out in 2015 - which could be perceived as a symbolic date in current Polish political history, since that was the election year that elevated Prawo i Sprawiedliwość (PiS) [the Law and Justice party] to power. PiS campaigned as a fairly moderate, modernising agent, but its political milieu is well known for its critique of the order built in Poland after 1989. After its seizure of power, PiS initiated a major shift in the way the modern history of Poland is presented and interpreted. Some of the central figures of 1989, such as Lech Wałęsa, the former Solidarity leader and president of Poland, are currently accused of having been in fact dependent on the political elites of the old regime. The whole breakthrough of 1989 in Poland is presented as a revolution that should have taken place but did not because the core of the 1980s opposition was too compliant during negotiations with the elites of the old regime. What was formerly praised as a peaceful transition is now criticised as a lack of determination in making a clear break with the past.

It is not difficult to see why this discussion is still so important, if we take into consideration the role of "peaceful transition" in liberal discourse. It was nothing less than a proof of the force of deliberation in politics. The vision that major systemic change was possible as an effect of elite negotiations was a suggestive success story for a certain vision of politics - one that accentuates the role of rational discussion among political lead- 
ers instead of, for instance, mass opposition to the system and its lack of legitimisation.

In opposition to this, the founding myth of those currently in power in Poland is what Sadura calls "the discourse of a 'stolen revolution" - which is the same belief held, for instance, by right-wing Hungarian political circles (see Sadura 2015: 24-26; the term "stolen revolution" is widely used by right-wing politicians and publicists). In Poland this narrative is a decisive reason for critiquing the post-transition order of the III Rzeczpospolita [Third Republic] as corrupted from birth, because the elites of the old system were not held accountable and were able to maintain their status - if not directly in politics, then at least in business, where they could guarantee their success by long-held connections and influence.

This conflict between two visions of the political change of 1989 - one highlighting its peaceful and rational character, the other its insufficiency and corruption - has somehow been reflected in scholarly discourse. The first is represented by accounts that perceived the revolutions in CentralEastern Europe - in Poland, Hungary, Czechoslovakia, and the GDR - to be classic and successful examples of "elite deliberation in the process of political transition." According to this view, the success of a transition to liberal democracy and capitalism was possible thanks to the pacification of popular sentiment and of the political process being kept in the hands of experienced political professionals. In this vision the aim of key processes was known: it was to build democracy and capitalism after years of authoritarian power and a planned economy. The motifs of the other narrative are present in critiques of the post-communist era as an interim period during which we should speak not of democracy and capitalism, but of specific power and economic structures that combined to produce an improvised reaction to external pressures (the world market and Western power structures) and political assets from the times of the old regime (see, e.g., Staniszkis 2005).

From this viewpoint, Sadura's book has been published at the right moment - when interpretation of the post-1989 events has been revealed to be urgent as both an academic and a political undertaking. Sadura is aware of the political aspect of his project. In the introductory chapters of his book he presents the importance of the discourses of "velvet" and "stolen" revolutions as popular political myths (Sadura 2015: 21-30). Second, he provides a critique of what he terms "transitology" - the above-mentioned political-science discourse of "elite deliberations." Sadura objects to its narrowed vision of politics, which reduces the process to what is some- 
times depicted as politics made in "smoke-filled rooms" (see, e.g., Fishkin 1991: 3) - elitist clubs that gather people with influence to arrange matters between themselves and set out the rules of the game. Sadura's main aim is to propose a different perspective - one that uses theories of revolutions to describe the fall of communism in East-Central Europe in all its complicated, multifaceted character.

This perspective involves several elements that should, according to Sadura, be put into the picture. First, there is the geopolitical level of analysis - the role of the USSR and the hegemonic Communist Party, as well as the pressure of Western political structures (such as the International Monetary Fund) and of global capital. This part of the model also involves the question of integrating different states with global capitalism. For instance, Romania remained relatively closed and self-sustainable until the dissolution of the regime, while Poland's industrial investments during the 1970s, financed by foreign credit, made it more dependent on global economic trends.

Second, there was the composition of the main political forces, which comprised not only moderate elites and the radical margins (as in the narrative about "elite deliberations"), but most of all, those interested in reforms and systemic change (both on the side of the Party and of dissidents and the wider political counter-elite) in opposition to those that were confrontation-oriented. This part of the model generates further questions that are crucial in describing the political dynamics of various crises: for instance, was it possible in the given situation to form a tactical alliance between reform-oriented actors? What was the role of external actors, that is, other states from the bloc and, most importantly, the hegemonic centre, the USSR and its ruling party? This part of the model deconstructs a cliché of trivialised historical narration that presents political conflicts inside the countries of the bloc as confrontations between "power" and "society" which are treated as completely opposing monoliths.

Third, an important factor is the dynamics of the system itself, evolving from its early Stalinist version through what Sadura terms its "bureaucratic" and "technocratic" varieties. Sadura presents those changes as a general process that slowly transforms the system's logic, though it does not develop without conflicts - sometimes of revolutionary potential - as in the case of Hungary in 1956 or Czechoslovakia in 1968. To develop this part of his model, Sadura distances himself from the notion of "totalitarianism" - which, once again, is too general a term to be used as an analytical tool. Bureaucratic regimes differed greatly from their Stalinist 
predecessors, although the changes were gradual in character and did not develop at the same pace across the bloc. Developing the theme of internal political dynamics allows Sadura to differentiate the countries of the region in terms of their susceptibility to crises, ability to react and transform the structures of power, and so on.

And lastly, a key factor is the class structure of the societies, each having its peculiarities that explain a great part of the dynamics of the political process. For example, we could take the changing role of the new middle classes - the professionals trained in order to provide cadres for industrialisation, which was one of the key elements of the planned economy. The "socialist" middle class was strongly integrated with the system and dependant on it during the "small stabilisation" period of the 1960s. This class was crucial in building support for the bureaucratisation of the system, which started to legitimise itself not by egalitarianism but by a gradual improvement in living standards (Sadura 2015: 161-163). The same middle classes were the force that backed the economic liberalisation of the system during the 1980s, at the same moment when the working class was losing its political force (Sadura 2015: 183-185). At the same time, the Polish workers' protests of 1976 and 1980 are interpreted by Sadura as a revolt against the alliance of the party establishment with the new middle classes of socialism (Sadura 2015: 167-168; Sadura draws here on the important work of Polish social historian Henryk Słabek, see Słabek 2015) - which is one of the most interesting theses put forward in the book.

The interplay of those factors is crucial for the model of revolution that Sadura applies to the main breakthroughs in the region, not only to the literal fall of communist regimes during the late 1980s and early 1990s. For instance, Sadura proposes that certain groups of events should be read as counter-Stalinist revolutions: from the insular workers' protests in the 1950s in the GDR, which were not politically integrated or developed and were quickly suppressed; through the full-blown revolution in Hungary in 1956; to the sort of belated de-Stalinisation in Czechoslovakia in 1968 (Sadura 2015: 151-158). In the case of Romania, certain important features of Stalinism - for instance, strong, personal leadership as a legitimising factor - were in place till the end of the regime in 1991.

The distinction between a revolutionary situation and a revolutionary change of power is important for the analysis. In Sadura's interpretation, the Solidarity movement was a revolutionary situation - although without a revolution in the sense of a takeover of power - that was possible mainly thanks to an alliance between a dissident sector of the upper class and the 
masses of politicised workers (see Sadura 2015: 171-172). In contrast to circumstances from the beginning of the decade, in the late 1980s the technocratic regimes of Hungary and Poland underwent "revolutions without a revolutionary situation." Toward the end of the 1980s, political actors on both sides - the Party as well as the opposition - were not interested in arousing mass protests and were generally inclined to adopt the neoliberal agenda being pushed by the IMF and Western creditors (see Sadura 2015: 183-196). This agenda would not have had popular support anyway.

Sadura uses a range of different materials, including interviews with political elites and statistical data from various widely circulated reports. Most importantly, he uses other historical and sociological analyses. His main ambition is not to discover some genuinely new material, but rather to put already known facts in a different perspective. Accordingly, his analyses are in principle brief and go straight to the point of how certain periods or specific events fit the model. He is clearly more interested in presenting general tendencies than in historical minutiae. His perspective is similar to that of several other sociologists who have also highlighted, for instance, the role of class dynamics in the transition from state socialism to capitalism. The work of David Ost (2006) or Elizabeth Dunn (2004) are important reference points, though Sadura's model is obviously more general in scope as it combines different levels into one explanatory and comparative model.

As legitimate as it may be, the method has its consequences in appearing at times to be a bit too sketchy, even for a sociological perspective, which is generally more interested in processes than in collecting historical details. For instance, as mentioned above, the very interesting point that the Polish workers' protests of 1970, 1976, and 1980 were in fact articulations of opposition to the system's withdrawal from egalitarianism is never properly developed. And it is precisely this point that would be of great significance for interpreting the nature and role of the new kind of elitist opposition that emerged in the late 1980s (and which was clearly different from the so-called "first Solidarity," which had had a mass character and was mainly a workers' movement), and the lack of mass protests toward the end of the decade.

Sustained polemics with different views of the revolutionary nature of the events described by Sadura would add to the picture. One of the most inspiring takes on the subject is Jadwiga Staniszkis's book Poland's Self-Limiting Revolution (1984 [2010]), which provides an interesting exposition of the strengths and weaknesses of the Solidarity movement as a revo- 
lutionary force in Polish politics. Staniszkis proposes her own take on the dynamics of "real socialism" as a political and social system. Second, she deals in detail with the class composition of the Solidarity movement and the consequences that its class character would have for the type of politics available to it (as her work was written in the early 1980s, it was almost "on the spot" of the most dramatic events of 1980-1982). She also provides a fairly convincing dialectical model of the tensions that would inevitably haunt Solidarity as a political force and limit the scope of its action. Sadura's interpretation of this view or his criticism of it would have been an interesting reference point and considerably more inspiring for the general aims of his book than a critique of the obviously sociologically flawed theory of elite deliberation.

Where Sadura succeeds - and this is an important achievement of his book - is in providing a model that adds a third option to the above-mentioned two main lines of interpretation of the 1989 events - the one of "peaceful transition" and the other of a "stolen revolution." The model in his book brings social classes back into the picture, showing the importance of social dynamics for every major political process in the region. It also shows that the revolution was not "stolen" in the sense of not providing a clear break with the past, because it in fact did change the basic coordinates of the region's political systems.

The real predicament of the systemic changes was not the dilemma between dependency on the old elites on the one hand (they were gradually removed from power in the region - if not outright in 1989 or 1991, then in the following years), and mythical "full sovereignty" on the other. The larger problem, and the more important stake of the late 1980s, was different. It can be put in a simple question: if not the fallen socialism, then what? As Sadura shows, the majority of Polish workers, who were the main driving force behind the revolutionary situation of 1980-1981, accepted the basic social aims of the system: social security and cohesion, low levels of income disparity, and so on. They wanted a system that would better serve those aims, not the restoration of capitalism. The same could be said for the majority of Romanians, the majority of people in Czechoslovakia, and the political elites that formed the oppositional "round table" in the collapsing GDR. What was discernible in these cases was a certain movement toward a kind of "third way" politics, a sort of democratised socialism with elements of a market economy, and not a version of capitalism entirely subjected to the demands of "monetarism" and neoliberal globalisation. Needless to say, it was utopian, but this was the real revolution 
that was "stolen" during the 1990s. If, then, the central political conflict of today between the conservative and liberal section of the political elites can be shown to be a conflict of two myths about the fall of communism (peaceful transition versus stolen revolution) then what Sadura sketches is a scholarly background for a third myth - let me call it the "myth of the third option," or of a "utopian possibility." That myth, for the time being, has no considerable political representation to reclaim its meaning and potential force.

Bibliography:

/// Dunn E.C. 2004. Privatizing Poland: Baby Food, Big Business, and the Remaking of Labor, Cornell University Press.

/// Fishkin J.S. 1991. Democracy and Deliberation: New Directions for Democratic Reform, Yale University Pres.

/// Ost D. 2006. The Defeat of Solidarity: Anger and Politics in Postcommunist Europe, Cornell University Press.

/// Sadura P. 2015. Upadek komunizmu w Europie Środkowo-Wschodniej w perspektywie wspótcresnych teorii rewolucji, Oficyna Naukowa.

/// Słabek H. 2015 [2009]. O spotecænej historii Polski 1945-1989, 2 ${ }^{\text {nd }}$ ed., Książka i Wiedza.

/// Staniszkis J. 2005. Postkomunižm. Próba opisu, Słowo/Obraz Terytoria.

/// Staniszkis J. 1984 [2010]. Poland's Self-Limiting Revolution, Princeton University Press [Polish edition: Samoograniczajaca sie rewolucja, Europejskie Centrum Solidarności].

/// Krzysztof Świrek - Ph.D., assistant professor at the Institute of Sociology, University of Warsaw. He specialises in critical social theory and modern political thought. His recent publications include: "Political Fantasy as a Form of Ideology - the Polish Case" (The Interlocutor: Journal of the Warsaw School of the History of Ideas 1/2017), and "Getting Hands Dirty: On Adam Schaff's Political Writings” (Hybris: Revista de Filosofía 37/2017).

Email:krzysztof.swirek@gmail.com 